\title{
Property and Freedom: A Beauvoirian Critique of Hume's Theory of Justice and a Humean Answer
}

\section{Propiedad y libertad: una crítica a la teoría de la justicia de Hume desde el pensamiento de Simone de Beauvoir y una respuesta humeana}

\author{
Dylan Meidell Rohr ${ }^{1}$ \\ John Christian Laursen ${ }^{2}$ \\ Universidad de California, Riverside (Estados Unidos)
}

Recibido: 12-06-18

Aprobado: 16-07-18

\begin{abstract}
David Hume and Simone de Beauvoir agree that human beings have a great deal of control over their moral and political lives, which is well captured in Hume's assertion that "mankind is an inventive species". But Hume argues that the most important thing needed to settle our social lives and determine justice is the agreement on rules of property, while Beauvoir thinks that the rules of property will never be enough to establish the best life, but rather that we should be focusing on freedom. In this article we reconstruct Hume's argument for property, then develop a Beauvoirian critique of Hume that brings out the weakness of any theory of property that does not prevent inequalities of property from interfering with freedom. And then we give the last word to a Humean response to Beauvoir that would insist that there can be no freedom but only violence without rules of property, which she ignores. Both thinkers appeal to humanity as an overriding goal, and perhaps that is the way to reconcile the two: we need both property and freedom to achieve our humanity.
\end{abstract}

Key-words: David Hume, Simone de Beauvoir, Property, Freedom, Humanity.

\footnotetext{
${ }^{1}$ (drohr001@ucr.edu) Enseña teoria politica en el departamento de Ciencia Politica de la University of California, Riverside.

${ }^{2}$ (johnl@ucr.edu) Profesor del departamento de Ciencia Politica de la University of California, Riverside
}

Araucaria. Revista Iberoamericana de Filosofia, Política, Humanidades y Relaciones Internacionales, año 20, $\mathrm{n}^{\circ} 40$. Segundo semestre de 2018. Pp. 421-445. ISSN 1575-6823 e-ISSN 2340-2199 doi: 10.12795/araucaria.2018.i40.19 


\section{Resumen}

David Hume y Simone de Beauvoir están de acuerdo en que los seres humanos tienen un grado muy importante de control sobre sus vidas morales y políticas; lo que está muy bien captado en la afirmación de Hume de que "la humanidad es una especie inventiva". Pero Hume argumenta que lo más importante a la hora de constituir nuestras vidas sociales y establecer la justicia es el acuerdo sobre las reglas de la propiedad, mientras que Beauvoir piensa que las reglas de propiedad nunca serán suficientes para establecer la vida mejor, sino que más bien deberíamos centrarnos en la libertad. En este artículo reconstruimos el argumento de Hume a favor de la propiedad, para desarrollar después una crítica basada en la perspectiva de Simone de Beauvoir que saca a la luz la debilidad de cualquier teoría de la propiedad que no evite que las desigualdades de propiedad interfieran con la libertad, Y después damos la última palabra a una respuesta humeana a Beauvoir que insistiría en que no puede haber libertad -sino solo violencia- sin reglas de propiedad, algo que ella ignora. Ambos pensadores recurren a la humanidad como el objetivo predominante, y quizás esta es la forma de reconciliarlos: necesitamos tanto de la propiedad como de la libertad para lograr nuestra humanidad.

Palabras-clave: David Hume, Simone de Beauvoir, propiedad, libertad, humanidad.

"Mankind is an inventive species", wrote David Hume in 1740, and went on to explain what he thought mankind had invented in matters of justice. Selfish acquisitive passions were so strong, he argued, that they can only be controlled by redirecting the same passions to support the rules of property. But is that enough for justice? Simone de Beauvoir, writing two centuries later, developed what can be understood as a critique of Hume's theory of justice as property via a critique of the actual status of the oppressed and of women in prevailing regimes of property in much of history and in her time. Her point is well taken that rules of property without any attention to equality of some sort among property holders will probably not achieve anything recognizable as justice. But her emphasis in her earlier philosophical writings on freedom without any recognition of the role of property in supporting such freedom leaves her open to a Humean critique. To the extent that she pays more attention to property in her magnum opus, The Second Sex (1949), that critique is mitigated, but it may still be said that her emphasis on freedom without an equal emphasis on property leaves the Humean critique with some traction.

Our argument will take the following steps: first, we will outline Hume's theory of justice as expressed in A Treatise of Human Nature. Then we will review some of Beauvoir's earlier works as well as her theory of ethics in The Ethics of Ambiguity (1947), and their alternative to and implicit critique 
of Hume's theory. Then we will bring in some materials from The Second Sex to show that by then she had realized the practical importance of property rights in the liberation of women. Finally, we will give the floor back to a Humean critique of Beauvoir's theory. We can hope that what will emerge will be a productive debate that clarifies the conceptual issues in service of a better understanding of property, freedom, and justice.

\section{Hume's theory of justice as rules of property}

At the age of 29, David Hume published the third volume of $A$ Treatise of Human Nature: Being An Attempt to introduce the experimental Method of Reasoning into Moral Subjects. Titled "Of Morals", Book III of the Treatise is only 103 pages long in the Oxford edition from $2000 .^{3}$ Yet it is packed with remarkable arguments and claims. As a note on method, we shall be concentrating here on this one book by Hume. Naturally, it should be read in the context of the ideas he had developed in volumes one and two. But since he noted at the beginning of the book that it was "in some measure independent of the other two, and requires not that the reader shou'd enter into all the abstract reasonings contain'd in them" (292), we are going to take that as license to concentrate mainly on this text. It would also be useful to cast our net forward in his writings to see how his ideas in this book were taken up or changed in his later writings, but we do not have the space for that, and we want to achieve the clarity that is possible by focusing on one set of ideas at one point in time. ${ }^{4}$

It is appropriate to start with Hume's assertion that "mankind is an inventive species" (311). Aristotle had argued that mankind is a political animal, and Edmund Burke was later to argue that it is a religious species, but Hume's emphasis is on the inventiveness of humanity. We are what we make of ourselves. We are not predetermined by nature or a divinity, in his analysis. And the most important area of our inventiveness is that of morals.

Philosophers and others who believe that they reason well like to think that moral ideas are a matter of reasoning and rationality. But Hume begins volume three with the argument that moral distinctions are not derived from reason (293). That may be a good thing, considering that if they did depend on reasoning, and how little reasoning most people have been (and still are) capable of, there would not have been much moral behavior in human

\footnotetext{
3 David Hume, A Treatise of Human Nature, eds. David and Mary Norton (Oxford: Oxford University Press, 2000). Hereafter cited in the text by page number in parentheses.

${ }^{4}$ On developments in his theory of justice, see Annette Baier, The Cautious Jealous Virtue: Hume on Justice (Cambridge: Harvard University Press, 2010). Hereafter cited in the text by page number in parentheses. She asserts that his later study of history taught Hume that "doing justice to each other comprises a lot more than respecting each other's property rights" (16-17). We shall see if that is true.
} 
history. But according to Hume the problem is that reason cannot make us want something, or love it or hate it. It is limited to the discovery of truth or falsehood (295), which cannot by itself make us want something. It may be true that it is "acknowledged by all mankind" that it is wrong to kill your own parents, but he insists that this prohibition is not a matter of fact or reason (300). Left alone, nature allows trees to kill their parents by growing up and putting them in the shade (300). So if we all feel that there is something wrong with killing your parents it is not a matter of fact or reason, he asserts, but of passions that are inculcated by nurture and become a feeling or moral sense. Similarly, murder by itself is just a fact, which can only be given a value by what Hume calls a "sentiment of disapprobation", not by reason (301). Hume proceeds to spell out what it means to say that moral distinctions are the product of a moral sense (302). This sense is natural in the sense that every nation has some sense of morals (305), but not in the sense that there is one set of possible moral distinctions set by nature. If nature is opposed to artifice, then it begins to look like moral distinctions may often belong to the latter (305). And Part 2 of Hume's book makes the case that justice is an artificial virtue.

Justice cannot be based on love of our neighbors, in Hume's view. "There is no such passion in human minds, as the love of mankind, merely as such" (309). Instead, we have to invent rules that will serve as a substitute for it. He insists that "when I deny justice to be a natural virtue, I make use of the word, natural, only as oppos'd to artificial. In another sense of the word; ...no virtue is more natural than justice. Mankind is an inventive species; and where an invention is obvious and absolutely necessary, it may properly be said to be natural as anything that proceeds immediately from original principles, without the intervention of thought or reflection" (311). Thus we are required by our condition to invent something that will serve the purposes of justice.

The need for justice is created by our partiality towards ourselves and our relations. There is no "inartificial principle of the human mind" (313) to counteract it. Rather, "our natural uncultivated ideas of morality... rather conform themselves to that partiality" (314). Fortunately, "nature provides a remedy in the judgment and understanding" once we realize that "the principal disturbance in society arises from those goods, which we call external", that is, property (314). That can only be done, Hume says, "by a convention enter'd into by all the members of the society to bestow stability on the possession of those external goods" (314). This convention is not a promise, but "a general sense of common interest" (314-5).

Hume situates property in juxtaposition to justice: "The same artifice gives rise to both" (315). In fact, it seems to be the main element of justice. He insists that "no one can doubt, that the convention for the distinction of property, and for the stability of possession, is of all circumstances the most necessary to the 
establishment of human society, and that after the agreement for the fixing and observing of this rule, there remains little or nothing to be done towards settling a perfect harmony and concord" (315-6). This is an astonishing claim. Is justice really all about property? That is Hume's claim, and maybe he is right. If we object that there are crimes of passion such as rape or murder, presumably the answer would be that most of them are really about property in some form or other. In any case, he asserts, "all other passions, besides this of interest, are easily restrain'd, or are not of such pernicious consequence" (316). "This avidity alone, of acquiring goods and possessions... is insatiable, perpetual, universal, and directly destructive of society" (316). This is another astonishing claim. Our desire for property is so pernicious? That is also Hume's claim, and maybe he is right.

If we have not thought about it much, we might be surprised to hear that property is such a fundamental element of justice. We may think fairness or reciprocity or equality are the important elements. But that may be because we take the rules of property so much for granted that we cannot even imagine what life would be like without them. What is at stake here is not whether or not we have fair, or only partly fair, or unfair rules of property. Hume's insight is that the rules of property are fundamental to any system that controls the natural violence of human beings. It would be an interesting intellectual exercise to rewrite any standard work on justice, such as Michael Sandel's Justice: What's the Right Thing to Do?, with an eye to bringing out the importance of property rules in every aspect of the determination of justice. ${ }^{5}$ It may turn out to be a more profound and thorough account of justice.

Fortunately, this dangerous passion can be manipulated to control itself. Hume argues that no other "affection of the human mind has both a sufficient force, and a proper direction to counter-balance the love of gain" (316). "There is no passion therefore, capable of controlling the interested affection, but the very affection itself, by an alteration of its direction" (316). Luckily, "upon the least reflection... 'tis evident, that the passion is much better satisfy'd by its restraint" (316). This is what is known as enlightened self-interest. Thus, by following the rules of property and "preserving society we make much greater advances in the acquiring possessions, than by running into the solitary and forlorn condition, which must follow upon violence and an universal license" (316).

Hume rejects the idea that justice is founded on reason and is universal and obligatory (318). If it were, we would hardly have to think about it. Rather, it is based on artifice and human conventions (319). We have the theme of inventiveness again: "men invented the three fundamental laws of nature"

\footnotetext{
${ }^{5}$ Michael Sandel, Justice: What's the Right Thing to Do? (New York, Farrar, Straus, 2009).
} 
and "self-love... is the first motive of their observance" (348). ${ }^{6}$ It is also the original motive for the rules of justice: "Tis self-love which is their real origin" (339). But then we come to understand their general benefit: "sympathy with the public interest is the source of the moral approbation, which attends that virtue" (320-21). And the beneficiaries do their best to cultivate that sympathy: this "progress of the sentiments" is natural, but also promoted by the "artifice of politicians" (321). They "teach us that we can better satisfy our appetites in an oblique and artificial manner, than by their headlong and impetuous motion" (334). Our "governors and rulers... being satisfy'd with their present condition, and with their part in society, have an immediate interest in every execution of justice, which is so necessary to the upholding of society" (344). Hobbes would say there can be no such satisfaction because no one is ever satisfied with their wealth and power but always needs more. And of course we could begin our critique with pointing out that even rulers can have an interest in injustices that favor them.

Property rights affect the other aspects of our life: "There is nothing that touches us more nearly than our reputation, and nothing on which our reputation more depends than our conduct, with relation to the property of others" (321). Yet they are only general rules. Justice does not try to assign particular goods to particular persons, because such decisions would be "liable to so many controversies" (322). Property rules are all based on the imagination and subject to change (324-7, with long note on the imagination, 327-9). In case anyone thinks that this is too arbitrary and contingent for something as important as justice, Hume insists that this is the case for all social values: "all morality depends upon our sentiments" (332).

Hume does not start from a high opinion of human nature. He believes that "men are, in a great measure, govern'd by interest" (342). And they prefer trivial present advantage to substantial future advantage (343). We have a "violent propension to prefer contiguous to remote" (344). So we learn to set up government to control ourselves by overriding the present interest in favor of the future (344). Government may have begun by consent, but "as soon as the advantages of government are fully known and acknowledg'd, it immediately takes root of itself, and has an original obligation and authority, independent of all contracts" (347). Paradoxically, although governments start with a convention, afterward "we naturally suppose ourselves born to submission" (355). So, rights can be created by nothing more than the passage of time. Leaders know that "time alone gives solidity to their right; and operating gradually on the minds of men, reconciles them to any authority, and makes

\footnotetext{
6 Although Hume often uses the words "mankind" and "human", he also uses the word "men" in contexts in which he clearly means all humans. Simone de Beauvoir also uses the word "man" [l'homme] when she means mankind. Later generations of feminists have disputed that practice, but we here adopt the practice of our two authors when quoting and commenting on their texts.
} Segundo semestre de 2018. Pp. 421-445. ISSN 1575-6823 e-ISSN 2340-2199 doi: 10.12795/araucaria.2018.i40.19 
it seem just and reasonable. Nothing causes any sentiment to have a greater influence upon us than custom" (356). "Time and custom give authority to all forms of government, and all successions of princes; and that power, which at first was founded only on injustice and violence, becomes in time legal and obligatory" (362). Justice, the laws of nations, and virtues such as modesty are "human contrivances for the interest of society. The inventors of them had chiefly in view their own interest. But we carry our approbation of them into the most distant countries and ages, and much beyond our own interest" (369).

Hume's only comment on the status of women in Book III is a discussion of what he calls the paradox of the rule about women's chastity, which is that it applies after menopause and thus when no longer necessary (365-6). He is not critical of the rule: he does not recognize that some men have raised other men's children, and that humans could invent a system in which many did. Sheridan Hough compares the ways in which Hume and Nietzsche discuss the artifice of female comportment. She argues that for Hume "the importance of chastity turns on a psychological claim about men." demand a kind of genealogical analysis. Why is it a universal and necessary fact that men need reassurances about paternity?"9 In fact, she points to another passage in Hume in which he seems to reject this very idea. ${ }^{10}$ It is true that, like Jeffrey Church suggests, according to Hume, social artifices "can only guide and assist our natural propensity to approve of agreeable or useful behavior and to disapprove of disagreeable or harmful behavior." "However, Hume does not prove that the desire for men to be assured of a child's paternity is actually natural. But perhaps more important, he does not explore the status of women in regimes of rules of property. He does not mention the point that women have often not been allowed to own property, and have even been considered property. So we do not know what his view of the place of women in justice is from this text.

Hume's conclusion is that "Tho' justice be artificial, the sense of its morality is natural" (395). He recognizes that "most of the inventions of men are subject to change. They depend upon humor and caprice. They have a vogue in time, and then sink into oblivion" (395), but "the interest, on which justice is founded, is the greatest imaginable, and extends to all times and places. It

${ }^{7}$ For more on Hume's understanding of custom, see John Christian Laursen, "David Hume on custom and habit and living with skepticism", Daimon: Revista Internacional de Filosofia 52, 2011, 87-99.

${ }^{8}$ Sheridan Hough, "Humean Androgynes and the Nature of "Nature", in Feminist Interpretations of David Hume, ed. Anne Jaap Jacobson (University Park: Pennsylvania State University Press, 2000), 220 .

9 Hough, "Human Androgynes...", 228.

10 Hough notes that Hume takes this position in "On Polygamy and Divorce" ("Human Androgynes...", 228),

11 Jeffrey Church, "Selfish and Moral Politics: David Hume on Stability and Cohesion in the Modern State", The Journal of Politics, 69, 2007, 171.

Araucaria. Revista Iberoamericana de Filosofia, Politica, Humanidades y Relaciones Internacionales, año 20, ${ }^{\circ} 40$. Segundo semestre de 2018. Pp. 421-445. ISSN 1575-6823 e-ISSN 2340-2199 doi: 10.12795/araucaria.2018.i40.19 
cannot possibly be serv'd by any other invention... All these causes render the rules of justice stedfast and immutable; at least, as immutable as human nature" (395). If a "Treatise of Human Nature" is going to capture the basic feature of human nature, it must focus on property as the basic element of justice.

Hume's argument is clearly abstract and philosophical. It does not trace any particulars of the history of property. It is conjectural history, and foreshadows his later use of "natural history", which is to say, a speculative presentation of the principles that must have underlain some development. Although his sketch of the rules of property from occupation to prescription to accession and succession obviously tracks Roman law, it is not presented as such but as a deduction from human needs and utility. One of the consequences of this method of reviewing the history of property is that he does not bring up the problems that any particular set of rules of property can cause nor discuss how to prevent them.

Note that Hume's abstract discussion of property does not take a stand on whether the property that determines so much of justice exists within a regime that permits private property in the means of production, or one that does not. Most socialist or communist regimes have permitted and regulated personal property, and have certainly defended and protected the property rights of the commune or state in the means of production.

There are reasons for thinking that the rules of property may be the most realistic way of controlling greed and violence. Knowing who is authorized to do what with what things and pieces of land helps us solve problems of coexistence and coordination. The invention of property in the service of enlightened self-interest may have been one of the most revolutionary developments in the inventive history of the species. Referring to Hume, one scholar once wrote that "to see justice this way, as an unintended consequence of individual human actions, must be one of the boldest moves in the history of the philosophy of law". ${ }^{12}$ But is it enough, and is it complete? Hume seems to be somewhat complacent: once the rules of property are established, is it really the case that "there remains little or nothing to be done towards settling a perfect harmony and concord"? (315-6).

\section{Simone de Beauvoir's alternative}

According to Simone de Beauvoir, freedom is the most important part of the human condition. Whether one is oppressed or the oppressor, one is always free. However, these freedoms are not equal. Because different people's freedoms are not always equal, and because, according to Beauvoir, one

${ }^{12}$ Knud Haakonssen, The Science of a Legislator (Cambridge: Cambridge University Press, 1981), 20. 
person's freedom is dependent on the freedom of others, it is necessary and beneficial for individuals to attempt to further their freedom and the freedom of others.

This is not an idealist argument which ignores the harsh limitations of the world. Her philosophy for an ethics of action and creation of meaning in the world is actually dependent on the existence of limitations. However, as Beauvoir makes clear in her 1945 essay, "Moral Idealism and Political Realism", one also must not get bogged down in the facts of the world and view them as being set in stone. Both pure moral idealism and pure political realism have the potential to lead to inaction or man's denial of his own freedom. In both moral idealism and political realism the individual attaches himself to a value or principle and rejects what Beauvoir believes ethics necessitates. She writes: "ethics is not an ensemble of constituted values and principles; it is the constituting movement through which values and principles are posited; it is the movement that an authentically moral man must reproduce for himself." 13 To be free is to act in the face of limitations. It is to transcend the given world. Like Hume's conception of man as an inventive species, Beauvoir argues that in the presence of adversity and collective action problems, mankind creates, maintains, and alters customs, norms, and meanings to better serve its needs. Rather than clinging to a particular set of moral ideals or realist beliefs about the world,

"since the political $\operatorname{man}^{14}$ cannot avoid questioning himself about the justification for his actions, and since a politics is not valid unless its ends are freely chosen, ethics and politics seem one and the same to us [...] Reconciling ethics and politics is thus reconciling man with himself; it means affirming that at every instant he can assume himself totally." ${ }^{15}$

Similar to Hume's assertion that people support property rights in the expectation that they will benefit from them, in one of her earlier philosophical essays, "An Eye for an Eye" (1946), Beauvoir writes that the "metaphysical basis for the idea of justice" is the "affirmation of the reciprocity of interhuman relations." 16 For Hume, the essential reciprocal interhuman relation necessary for justice is the protection of property rights. For Beauvoir, because people are free, and because justice is dependent on reciprocity, the main concern is the

13 Simone de Beauvoir, "Moral Idealism and Political Realism" in Simone de Beauvoir: Philosophical Writings (Urbana: University of Illinois Press, 2004), 188.

14 The political man is understood not as a mere politician or "political technician", but as one who "intends to map out the world to come" or "who has the audacity to choose his ends and to reach them without allowing taboos to get in the way" ("Moral Idealism", 189, 187).

15 Simone de Beauvoir, "Moral Idealism", 189.

16 Simone de Beauvoir, "An Eye for an Eye" in Simone de Beauvoir: Philosophical Writings (Urbana: University of Illinois Press, 2004), 249. 
ability of people to use their freedom equally. Though this may never be fully actualized, it is still a worthwhile end. This is why Beauvoir writes in Pyrrhus and Cineas (1944) that "Our freedoms support each other like the stones in an arch, but in an arch that no pillars support". ${ }^{17}$ In order for me to be free, you must also be free - an equality of freedom is necessary. Property rights are not sufficient for the establishment of this idea of justice.

Beauvoir addresses the importance of self-interest in The Ethics of Ambiguity when she writes that "no moral question presents itself to the child as long as he is still incapable of recognizing himself in the past or seeing himself in the future". ${ }^{18}$ In other words, individuals must be able to see and recognize their self-interest in order for a sense of morality to arise in them. If they do not recognize themselves as ends, worthy of pursuing, Beauvoir suggests that individuals would have no sense of moral or immoral behavior. Moral behavior, for Beauvoir, is intimately linked with individuals being treated as ends in themselves. This thought extends to sympathy. If one does not see others as ends worthy of their own pursuits then one cannot treat them morally. This ability to see another person as a project in its own right is what Beauvoir suggests is moving about a child's face. She writes, "it is not that the child is more moving or that he has more of a right to happiness than the others: it is that he is the living affirmation of human transcendence: he is on the watch, he is an eager hand held out to the world, he is a hope, a project" (EA110). Those who fail to see others as projects and instead see them as mere means to their own ends are tyrants, she says (EA110).

"[Man] can become conscious of the real requirements of his own freedom, which can will itself only by destining itself to an open future, by seeking to extend itself by means of the freedom of others. Therefore, in any case, the freedom of other men must be respected and they must be helped to free themselves" (EA65). Though she recognizes that it is natural to be more sympathetic to oppression that affects a person or those close to him, Beauvoir suggests that even so, "through his own struggle he must seek to serve the universal cause of freedom" (EA96). Indeed, according to Beauvoir, "no existence can be validly fulfilled if it is limited to itself. It appeals to the existence of others. The idea of such dependence is frightening" (EA72). While people are able to act and create, they are also dependent on others to act and create in ways that do not oppose or oppress others.

\footnotetext{
17 Simone de Beauvoir, Pyrrhus and Cineas, in Simone de Beauvoir: Philosophical Writings (Urbana: University of Illinois Press, 2004), 140. Hereafter cited in the text by the letters PC and page number.

18 Simone De Beauvoir, Pour une morale de l'Ambiguité (Paris: Gallimard, 1947). Hereafter cited in the text by the letters EA and page number from the English edition, The Ethics of Ambiguity, tr. B. Fruchtman (New York: Philosophical Library, 1948), here at 27.
} Segundo semestre de 2018. Pp. 421-445. ISSN 1575-6823 e-ISSN 2340-2199 doi: 10.12795/araucaria.2018.i40.19 
Unlike Hume, in The Ethics of Ambiguity Beauvoir has little to say about property, and what she does say is all negative. She agrees with Hume that property regimes are human inventions. But the ones we have are not just ones. "Conservatives" who defend the present distribution of wealth try to present it as a "natural fact" but the revolutionaries recognize that "the present regime is a human fact" (EA89). The property associated with the Parti Républicain de la Liberte is based on the exploitation of the working class and thus is not freedom for everyone but rather only freedom for a few (EA96). It is a "freedom which is interested only in denying freedom" (EA97).

Beauvoir finds that it is precisely because of various sorts of ambiguity that we have freedom. Like Hume, she takes issue with the idea that either the mind or the body is supreme. She asserts that all men feel the ambiguity of body and mind, and accuses philosophers of trying to obscure this ambiguity. Philosophers have "striven to reduce mind to matter, or to reabsorb matter into mind, or to merge them within a single substance" (EA7). She observes that most who have tried to ignore this ambiguity and create an ethics have fallen into one of two camps. One is focused purely inwardly, the other purely externally. One either closes oneself off from the real world, or loses oneself in the world (EA6). For Beauvoir, if one is concerned with morality, one cannot simply focus internally and morality cannot be known from reason alone. Like Hume, she takes issue with the idea that morals are learned from reason. That position suggests that mind is supreme over matter or the body. She also takes issue with the idea that the body reigns over the mind, and insists that it is important to recognize that both are influential and have their own role in the development of morality and ethics. This ambiguity creates an opening for freedom. The general argument is that we can choose between ambiguous choices. And our inventiveness grows out of that. Or in other words, ambiguity makes freedom possible.

Similar to Hume's view that mankind is an inventive species, Beauvoir recognizes the role of man's creative abilities in constructing the world in which he inhabits. Of man, Beauvoir writes, "he bears the responsibility for a world which is not the work of a strange power, but of himself, where his defeats are inscribed, and his victories as well" (EA15). She continues, "one can not start by saying that our earthly destiny has or has not importance, for it depends upon us to give it importance" (EA15). But this power of invention is not limitless. Rather, she asserts that man does not freely create the world, but that "the will [of man] is defined only by raising obstacles, and by the contingency of facticity certain obstacles let themselves be conquered, and others do not" (EA28). This is another aspect of what she sees as the ambiguous nature of man. "The more widespread their mastery of the world, the more they find themselves crushed by uncontrollable forces. Though they are masters of the atomic bomb, yet it is created only to destroy them" (EA7). 
Beauvoir sees this ability to invent, form, and influence the world as central to what it means to be human. The condition of man is freedom and that is also man's ultimate end even though we live in a situation which at times severely limits our freedom. Though Beauvoir believes freedom is central to the condition of man, she also recognizes that this is hidden from some. She writes, "this misfortune which comes to man as a result of the fact that he was a child is that his freedom was first concealed from him and that all his life he will be nostalgic for the time when he did not know its exigencies" (EA43). Man often feels as though he is not free and not able to influence the world around him. Many of the horrors of the world are a result of man's complicity in choosing not to act. By this rejection of freedom, man is therefore responsible for not protesting the ways in which others are subjugated (EA40-41). For Beauvoir, it is important to recognize our power and ability to influence the world around us - even if that influence and ability to act is limited. As she writes, "to be free is not to have the power to do anything you like; it is to be able to surpass the given toward an open future; the existence of others as a freedom defines my situation and is even the condition of my own freedom" (EA97). This latter gives a reason for acting: one's own freedom is enhanced by the freedom of others. Perhaps this is also a type of enlightened self-interest.

Of course, acting to free others in order to free oneself is a possible description of Hume's view of property. In the abstract, everyone gets more freedom from violence if the rules of property are respected. If Beauvoir were more of a Humean, she might have argued that our own freedom is enhanced by the property of others. But in property regimes as we know them, not everyone has equal property and not everyone is equally free, and the freedom that many should have is hidden from them. With this kind of critique, Beauvoir could draw attention to the fact that there is no mention in Hume of problems with great disparities of property, nor of people as property (slaves and women). Thus, Hume could be missing the point, as Molly Farneth writes, that "if existential freedom entails contributing to the ongoing process of remaking the social world, then one person's freedom entails all people's freedom" and his complacency about property rules "impedes others' freedom to remake the world by guarding the inherited world from challenge." 19 He seems to be taking certain elements of the world to be facts which cannot be altered or changed.

In The Ethics of Ambiguity Beauvoir also recognizes the fact that in many circumstances women have been kept in a position where they are apt to accept and even rely on their positions of subservience. She writes that women and slaves are "beings whose life slips by in an infantile world because, having been kept in a state of servitude and ignorance, they have no means of breaking

\footnotetext{
${ }^{19}$ Molly Farneth, "James Baldwin, Simone de Beauvoir, and the 'New Vocabulary' of Existentialist Ethics,” Soundings: An Interdisciplinary Journal, 96, 2013, 177.
} 
the ceiling which is stretched over their heads. Like the child, they can exercise their freedom, but only within this universe which has been set up before them, without them" (EA39). For many women, the world around them is one which has been formed by men, for men. Women exist in the world, but it is not a world made with them in mind. While some recognize this neglect of women and think of it as despicable, other women, Beauvoir suggests, "take shelter in the shadow of men; they adopt without discussion the opinions and values recognized by their husband or their lover, and that allow them to develop childish qualities which are forbidden to adults because they are based on a feeling of irresponsibility" (EA40). Though Beauvoir recognizes that some, such as slaves, are in a position in which they truly do not choose to be complicit in their subjugation, others, such as some women in the western world in the modern era, are complicit in their own subjugation.

It is well known that Beauvoir's most influential contribution to twentieth century political philosophy was The Second Sex. ${ }^{20}$ In this volume her analysis of the status of women is much more developed and nuanced. One element of the subjugation of the female sex is the institution of property: "it is the social regime founded on private property that brought about the married woman's wardship" (SS149). Of the tension between man and woman, Beauvoir writes, "Everything he wins, he wins against her; the more powerful he becomes, the more she declines. In particular, when he acquires ownership of land, he also claims woman as property. Formerly he was possessed by the mana, by the earth: now he has a soul, property; freed from Woman, he now lays claim to $a$ woman and a posterity of his own" (SS87). As women have historically often been kept from certain kinds of employment that would allow them to live without depending on a man, and because they have also sometimes been kept from owning private property, the life and subjugation of women is entwined with the existence of private property and inheritance. Beauvoir writes that, "because she owns nothing, woman is not raised to the dignity of a person; she herself is a part of man's patrimony, first her father's and then her husband's" (SS204). Most women have been kept in a position of being unable to own private property since its advent. Because of this, according to Beauvoir, women are seen as being less than full moral beings, and in fact, property of men.

As we have seen, Hume discusses property in general and in abstraction, such that it could be referring to any sort of property, private, communal, or state. We have seen that in one of her books she criticizes one form of private property, but one should note that a Beauvoirian would also have to recognize

${ }^{20}$ Simone de Beauvoir. Le Deuxième Sexe (Paris: Gallimard, 1949) Hereinafter cited in the text by the letters SS and by page number from the English edition, The Second Sex, tr. Constance Borde and Sheila Malovany-Chevallier (New York: Vintage Books, 2009).

Araucaria. Revista Iberoamericana de Filosofia, Política, Humanidades y Relaciones Internacionales, año 20, ${ }^{\circ} 40$. Segundo semestre de 2018. Pp. 421-445. ISSN 1575-6823 e-ISSN 2340-2199 doi: 10.12795/araucaria.2018.i40.19 
the limits or failures of communal and state property as bases for justice in society.

Regarding communal property, we shall focus on several aspects of Beauvoir's discussion of Sparta. Beauvoir suggests that in Sparta - a society in which community property prevailed — women were treated "almost as the equal of man" (SS96). Beauvoir even suggests that Plato "aspiring to a communal regime, promised women a similar autonomy to that enjoyed in Sparta" (SS130). However, while Beauvoir believes Spartan women were somewhat more equal to men as a result of a society based on communal property, she also recognizes that male oppression was still prevalent (SS66). She claims that in societies such as Sparta and Nazi Germany in which women were made less erotic, but more dependent on the state, women had "both more and less autonomy than a bourgeois woman living under a capitalist regime" (SS146). So Beauvoir recognizes both the benefits and the drawbacks of societies based on communal property such as Sparta. A Beauvoirian could argue that this suggests that merely changing from private property to communal property rights would not guarantee justice as it does not recognize the issues of women and address them adequately.

The same argument can be made for state property. What Beauvoir said about the Soviet Union provides some insight into why a Beauvoirian would also suggest that justice cannot be attained merely by securing property rights for the state. Beauvoir suggests the goal of a socialist society would be the elimination of the distinction between men and women, and the recognition of individuals only as workers (SS64). Beauvoir argues that this sentiment was present in Lenin's thought, which linked women's liberation to the liberation of workers. He aimed or desired to give them political and economic equality (SS147). Though this may be the goal of the creation and protection of state property, Beauvoir also recognizes that patriarchy was never eliminated from the USSR. She observed that patriarchy in marriage practices, the eroticization of women, as well as other aspects of the ways in which the USSR chose to organize its economy and property did not lead to the liberation of women (SS67).

In both the creation of communal and state property rights, women have been relegated in many ways to second class citizenship. In these instances, rather than being an end in herself, woman in society is merely seen as an instrument or tool for stable property practices. This continues to be the case when Beauvoir discusses private property. According to Beauvoir, the need for the male sex to protect its possessions is in part responsible for the tradition of marriage as well as the belief that infidelity on the part of women is a high crime. She states that "Marriage rites were originally intended to protect man against woman; she becomes his property [...]" (SS204). In part, what man 
could need "protection" from could be the infidelity of women, as Hume's discussion of women suggests. In order to keep men true and faithful to their families, they must believe that their children are indeed their own, in both private property and communal property regimes. In other words, when only men may own property, women are used as a means of maintaining the stable possession and transfer of property rather than as ends in themselves. Because of this Beauvoir writes,

"As long as private property lasts, conjugal infidelity on the part of a woman is considered a crime of high treason [...] under the patriarchal regime, she was the property of a father who married her off as he saw fit; then attached to her husband's household, she was no more than his thing and the thing of the family (genos) in which she was placed" (SS91).

Though Hume believes property is the heart of the artifice of justice, Beauvoir's account implies that it cannot be totally just if it is dependent upon the idea of subjugation and domination of women.

The critique is that while Hume believes the protection of property is the major element of justice, the way in which this artifice has come about throughout history has been at the expense of women, for reasons that Hume does not adequately explain or defend. This could be in part because of the fact that, as Sonia Kruks interprets Beauvoir's critique of Engels, "it is only given certain already-existing values, including the desire to dominate the other, that the development of private property could have facilitated women's subordination". ${ }^{21}$ Thus Beauvoir believes that the paternity-based reason for the control of women is not the whole story. There must also be a desire to dominate the other prior to this concern. So while Hough suggests there is hope for Hume's philosophy to be supportive of women due to its discussion and focus on sympathy, it appears as though his idea of justice is still rooted in impressions and desires which seek to subjugate women to men. ${ }^{22}$ Though this subjugation may produce order and stability as Hume believes it does, one must ask whether this conception of the basis and invention of justice is truly just.

If it is true that property rights are the origin of justice, then perhaps one could say Beauvoir could be a Humean in the advocacy of property rights as long as they are extended to men and women equally. Beauvoirians could, in theory, agree that justice arose from property. However, they would also argue that it must move beyond that. Extending property rights to women has made women's situation better - even if they originated as sexist tools to control and oppress women. Though property rights in and of themselves can still be seen as problematic, that does not have to mean that women should not enjoy

${ }^{21}$ Sonia Kruks, “Ambiguity and Certitude in Simone de Beauvoir's Politics”, PMLA, 124, 2009, 217.

${ }^{22}$ Hough, "Humean Androgynes", 236.

Araucaria. Revista Iberoamericana de Filosofia, Politica, Humanidades y Relaciones Internacionales, año 20, ${ }^{\circ} 40$. Segundo semestre de 2018. Pp. 421-445. ISSN 1575-6823 e-ISSN 2340-2199 doi: 10.12795/araucaria.2018.i40.19 
their benefits, whether or not they benefit women to the same degree as they benefit men. However, Hume's conception of justice based in the protection of property is still too narrow. Protecting property, as Hume suggests, may help in some ways, but is not the panacea he may have believed it to be.

Protecting property does not account for the ways in which women's situatedness necessitates more particular requirements for justice. Among those concerns Beauvoir feels would create equality between men and women are: women should receive the exact same education as men and have identical working conditions and salaries; women would be obliged to work; marriage would be freely engaged in and freely broken; birth control and abortion would be legal; maternity leave would be provided by society - but this does not mean that children are taken from their parents nor that children are abandoned to their parents (SS760). From this list, it is clear that even if Beauvoir were in favor of extending property rights to women-even if it were to the fullest extent as men-Hume's conception of justice would still be left wanting. It is not bad to extend property rights to women, according to Beauvoir, but it is incomplete.

Justice based in the protection of property does not fully recognize the ways in which the freedom of women has been curtailed in society. The differences between men and women, both biological and sociological, according to Beauvoir, mean that in order to be equal in society - i.e. to be able to act equally freely - these differences must be taken into account. One cannot simply bring women into the fold of pre-existing conceptions of justice based in property rights and expect society to be just. One must also take the differences between men and women and explicitly conceptualize how to mitigate the effects of those differences so that men and women can truly live more equally and thus more justly. As Beauvoir writes, "To demand for woman all the rights, all the possibilities of the human being in general does not mean one must be blind to her singular situation" (SS67). By recognizing and accounting for these differences, as well as trying to mitigate the adverse effects, men and women can move beyond the explicit and implicit oppression of women and instead "unequivocally affirm their brotherhood" (SS766).

Though Beauvoir is opposed to tyrannical government just as Hume is, her text is more nuanced in the way it recognizes that not only is broad systemic justice important, but so, too, is individual ethics. In fact, one could see that while systemic injustice is abhorrent, opposing a tyrannical system may not do much if individuals are not compelled to change their behavior as well. One must be able to bring about meaningful change. After all, if people do not recognize that it is one's ethical responsibility to fight for the freedom of themselves and others, how would one expect there to be opposition to tyrannical regimes in the first place? Beauvoir writes, "Ethics is the triumph over facticity" (EA48). 
We are all limited in different ways, but when we act and create in ways that empower ourselves and others to rise above our circumstances, to see ourselves and others as ends, we are ethical.

Though Hume's text asserts that morality and justice are man-made, he does not insist on the ability, or requirement, of man to see one's life as an individual project — part of which is to fight for the freedom of others. Rather, Hume suggests that it is necessary that we "know our rank and station in the world, whether it be fix'd by our birth, fortune, employments, talents or reputation. 'Tis necessary to feel the sentiment and passion and pride in conformity to it, and to regulate our actions accordingly" (382). Beauvoir has a broader notion or understanding of oppression in the world than is evident in this observation of Hume. While she would certainly agree that there can be value gained from understanding one's place in the world, this does not mean that one necessarily must "regulate our actions accordingly." Rather, it seems evident that Beauvoir in many, if not most, circumstances would argue that people have an obligation to themselves and others to rise up and stand in opposition to what is expected of them-whether it be women, slaves, or the proletariat. Michèle le Doeuff writes that, "When Simone de Beauvoir describes the repetitive nature of housework, when she analyzes the censorious treatment of aggressiveness in little girls, when she sets out notions on female frigidity, when she examines the prevailing conception of women's wages as 'salaire d'appoint' supplementing the husband's earnings, she provides essential elements of a detailed and precise consciousness of women's oppression." ${ }^{23}$ As we have suggested, Beauvoir has a broader view of oppression than Hume, which would then insist that it is not just in the face of government tyranny that one must rise and oppose injustice. Beauvoir would not be surprised that Hume and others do not see the above mentioned ways in which women are oppressed as oppression. For as le Doeuff writes, "she can see oppression where the dominant discourse says there is protection, or seduction, or, worse, duty." 24 Rather, injustice should be sought out, interrogated, and attacked wherever one finds it, whether in the government, work place, or even nuclear family. Hume did not mention injustices or inequalities of power within the family, for example. On the topic of the family, Church writes,

The family is the origin of society, but it is also a microcosm of it. Parents establish general rules of moral behavior both to regulate family life, but also to prepare their children for success in civil society. Society itself has a number of mores by which we must regulate our behavior so as to attain success and praise with our honor and wit. The market and the regime set down certain laws

${ }^{23}$ Michèle Le Doeuff, "Simone de Beauvoir and Existentialism”, Feminist Studies, 6, 1980, 277.

24 Le Doeuff, "Simone de Beauvoir...", 279. 
which we must obey in order to maintain a thriving business or get reelected into office. ${ }^{25}$

Others, such as Susan Moller Okin, would argue that this is problematic because the way the nuclear family is commonly structured is itself not just. Okin writes that "the sexual division of labor within the family, in particular, is not only a fundamental part of the marriage contract, but so deeply influences us in our most formative years that feminists of both sexes who try to reject it find themselves struggling against it with varying degrees of ambivalence. Based on this linchpin, the deeply entrenched social institutionalization of sex difference, which I will refer to as 'the gender system' or simply 'gender,' still permeates our society". ${ }^{26}$ This sentiment is similar to Beauvoir, who throughout her work discusses the ways in which at every turn women are subjugated to men, both in the family and in turn in society at large. Just as one may ask after reading Beauvoir how one can have valid system of justice based on property when women have been historically excluded from owning property and also treated as property, one may also ask how a system can be just if the idea of justice began in the household, which itself is often unjust? But, of course, if women are allowed to own property, and families become egalitarian, this objection would disappear.

It is true that Hume does not seem to be overly concerned with differences in power in the development of morals and other human artifices. If it is true that they are man-made, it is not true that all men have the ability to equally influence and change these rules and customs. Hume writes as if all are equal when he observes that "I learn to do a service to another, without bearing him any real kindness; because I forsee, that he will return my service, in expectation of another of the same kind, and in order to maintain the same correspondence of good offices with me or with others" (371). As a methodological individualist in this instance, the method by which an individual learns social norms and expectations is discussed as if the two individuals are on a completely equal footing. While it is true that in some circumstances this may be the case, Hume does not seem at any point to adequately deal with the fact that in most known societies some, or even most, people are kept in a position in which their behavior is futile. Alhough man is an inventive species, not every man is given the opportunity to exercise the ability to invent in society. Hume briefly touches on the ways in which women have been controlled by men, but that brief section does not do justice to the importance of differing power relations in society. This topic is by no means the exclusive point of Beauvoir's work, but the position of child-like subservience in parts of the population such as women and slaves is more openly acknowledged by her than by Hume.

${ }^{25}$ Church, "Selfish and Moral Politics", 176.

26 Susan Moller Okin, “Justice and Gender", Philosophy and Public Affairs, 16, 1987, 42. 
Though insisting that existential ethics is an ethics in which one is only truly free when others are free may sound idealistic and devoid of "real world" concerns of power, Beauvoir does explain that in some cases, killing another individual may be necessary. Beauvoir writes, "When a young sixteen-year old Nazi died crying, 'Heil Hitler!' he was not guilty, and it was not he whom we hated but his masters. The desirable thing would be to re-educate this misled youth $[\ldots]$ But the urgency of the struggle forbids this slow labor. We are obliged to destroy not only the oppressor but also those who serve him, whether they do so out of ignorance or out of constraint" (EA105). Beauvoir also says that Hegel, Stalin, and the fascists are wrong to claim that group rights override individual rights. "A doctrine which aims at the liberation of man evidently can not rest on a contempt for the individual" (EA111) and the theory that says that one should willingly sacrifice oneself for the group is "self-contesting" (EA112). She asserts that "the collectivist conception of man does not concede a valid existence to such sentiments as love, tenderness, and friendship" (EA116). This means that "the defender of the U.S.S.R. is making use of a fallacy when he unconditionally justifies the sacrifices and the crimes by the ends pursued" (EA158). Rather, he should recognize the ambiguities and uncertainties of any political commitment (EA159). For Beauvoir, that is not a bad thing: it is ambiguity which allows for freedom. It was brave of her to admit in mid-1940's Paris that Stalin was sometimes wrong.

Beauvoir would have to admit that the protection of property rightsprivate, communal, and state - has led to greater stability, order, and peace in society, as Hume suggested. While protection of property may be necessary for justice in society, she would say it is not sufficient. This has been suggested by the ways in which Beauvoir finds that in different social structures that rest on different forms of property, there is still oppression - of women as well as other groups. These societies may be orderly, but they may not be just. Rather, Beauvoir's description of justice being based in the reciprocity of interhuman relations makes clear that justice is dependent on much more than protection of property. This basis for justice, along with the central themes at the core of much of Beauvoir's philosophy, suggest that rather than property, justice is secured when individuals are seen as ends by themselves as well as others. For this to occur, people must aspire to not only ensure their own freedom, but the freedom of others.

\section{A Humean critique of Beauvoir}

The Ethics of Ambiguity and most of Beauvoir's other early philosophical writings are all about freedom and choices, with no significant attention to 
property rights. Their implicit critique of the Humean theory of justice for underplaying the importance of inequalities of property and of property in people is probably well-taken. But a Humean could push back, saying that property is still the most important element of justice, and that those inequalities can be fixed. Hume could certainly agree with Beauvoir when she wrote that "the task of man is one: to fashion the world by giving it meaning". ${ }^{27}$ That sounds like Humean invention. But what sort of meaning? How will violence be suppressed, or will we just have to live with it? Beauvoir's formula provides no clues about the answers to these questions, while Hume's reliance on the invention of property spells out some answers. In the following, we will develop some of these Humean answers as a critique of Beauvoir. We do not mean to say that this is what Hume did in fact say, but that someone who takes up Hume's insistence on the importance of property rights in the making of justice could make these arguments.

Since Hume's argument is mostly abstract and philosophical, we can expand on it by relying on another abstract and generalizing philosopher. Lawrence C. Becker's exploration of the philosophical foundations of property rights distinguishes those foundations into several categories. One of them is the argument from utility. This argument points out that we could not do much in the way of carrying out our purposes of any type if we do not have reliable access to tools and materials. ${ }^{28}$ Beauvoir writes about freedom as if freedom does not depend on property rights, but at this point the Humean could ask Beauvoir how she thinks people could carry out their purposes without property rights? What is freedom if it does not include carrying out our purposes? What choices could you make in Beauvoir's vaunted situations of ambiguity in conditions of complete instability of property?

A second utility of property is that the acquisition, possession, and use of things may be necessary for the creation of personality. ${ }^{29}$ Beauvoir is very much into individuals making choices, but does she realize that the phenomenological basis of individuals as we know them is their property? The Humean could insist that you cannot think of yourself as an independent individual if you do not have some property that is safe from the control or even violence of others. That there can be no justice without property is a strong, but very Humean, point.

A subset of personality development is the development of the child. As we have seen, Beauvoir is very interested in the phenomenology of the child. Doesn't the child also need to think of things that are mine in order to have the

${ }^{27}$ Simone de Beauvoir, "What is Existentialism?" (1947) in Simone de Beauvoir: Philosophical Writings (Urbana: University of Illinois Press, 2004), 325.

${ }^{28}$ Lawrence C. Becker, Property Rights: Philosophic Foundations (London: Routledge and Kegan Paul, 1977), 62.

${ }_{29}$ Becker, Property Rights, 63.

Araucaria. Revista Iberoamericana de Filosofía, Política, Humanidades y Relaciones Internacionales, año 20, $\mathrm{n}^{\circ} 40$. Segundo semestre de 2018. Pp. 421-445. ISSN 1575-6823 e-ISSN 2340-2199 doi: 10.12795/araucaria.2018.i40.19 
self-respect it needs to see itself as an end? Can we develop full personalities while thinking that everything outside of our bodies is beyond our control? At the least, that would be a different personality than any we have yet seen. Even if it is not beyond the inventiveness of human nature to develop such a personality, are we sure we want to? There may be unintended consequences. If everything outside of our bodies is outside of our control, it might be difficult to continue to think that our bodies are under our own control.

One of the arguments for property rights is the argument from political liberty. It centers on the point that the effective prohibition of human beings' desires to acquire things and control them and exclude others from their use would require a comprehensive and continuous abridgment of people's liberty. ${ }^{30}$ No property, no liberty, could be the Humean's slogan.

The Humean does not need to reject Beauvoir's criticisms entirely. $\mathrm{He}$ or she could answer that Hume was only sketching the largest principles, and that none of them would prevent us from getting the details of property right: great disparities and property in people could certainly be prohibited. It is true that Hume defends the requirement that a poor man return a pledge to a rich one as a general principle (308ff). But that does not rule out exceptions, among other things in cases of necessity. It does rule out that across the board anybody who borrows anything can decide whether to return it based upon needs and deservingness at that time. But if that were the standard for loans, and we were constantly reevaluating returns of borrowed items, what would happen? Would anybody loan anything?

It is true that Hume does not say anything about the need for some level of equality of property ownership in the Treatise. But in his rewriting of his theory for more popular consumption in the Enquiry concerning the Principles of Morals he imagines the case of living with some creatures who "though rational, were possessed of such inferior strength of body and mind, that they were incapable of all resistance, and could never, upon the highest provocation, make us feel the effects of their resentment" and concludes that in such a case we would not "properly speaking, lie under any restraint of justice with regard to them, nor could they possess any right or property" $(191) .{ }^{31}$ The logic here is that property is an implicit agreement for mutual restraint, and if one side could not take the other's property or stop the other from taking theirs, there would be no reason for restraint on the side of the other. On the one hand, this could sound like a justification for robbery and cruelty, but on the other hand it may be Hume's way of claiming that the remedy here is not justice, but rather that we "should be bound by the laws of humanity to give gentle usage" $(191)^{32}$. This

\footnotetext{
${ }^{30}$ Becker, Property Rights, 63.

${ }^{31}$ David Hume, Enquiry concerning the Principles of Morals, ed. L. A. Selby-Bigge (Oxford: Clarendon Press, Third Edition, 1975), 191.

${ }^{32}$ Ibid.
} 
may be a way of saying that justice narrowly construed is only about respecting the rules of property, but that the laws of humanity can do much more.

If it may be true that Hume's account of justice as property is complacent in some respects, it may also be true that Beauvoir's account of freedom is complacent in its own way. Recall that Hume's chief concern is diminishing violence in human society. Beauvoir does not seem so concerned. In Pyrrhus and Cineas she recognizes that violence is common because man covets the goods of others (PC94) and is divided and in conflict with himself (PC138). She attempts to lessen our opposition to violence on the ground that in one sense it is not an evil (PC138). Violence creates slavery, but, for example, slavery doesn't change the freedom of the slave (PC124). On the other hand, as we have seen, she also recognizes that some who have been "kept in a state of servitude and ignorance, [...] have no means of breaking the ceiling which is stretched over their heads" (EA39). Thus, while all people are free, some are better able to make use of their freedom than others. If we value our own freedom, she argues, we must fight to further the freedom of others. And she also points out that violence can destroy the very freedom that she favors (PC137). A Humean would say she should recognize the importance of property in preventing this violence. The Humean could indeed recognize that there is a lot about inventiveness in her account, but object that it is all about the individual holding on to inventiveness even in difficult circumstances. But the Humean would argue that we also need something more systematic than individualism in the face of violence.

Annette Baier's portrait of Hume's philosophy makes him into a more sympathetic thinker for modern purposes. She thinks he would have supported the North in the American Civil War and the civil rights movement in the United States (54). She writes of his support for the Levellers in the English Civil War (62) and his opposition to slavery and the exclusion of women from owning property $(81,111)$. Her assertion that "Hume recognizes a right to rebel against tyrannical rulers, but not against unfair or oppressive property conventions" can be answered by observing that he simply did not raise the issue (52). Insisting that property rules are of overriding importance does not imply that unfair ones are acceptable. Her list of what justice can include that goes beyond property such as "fair trials, fair return on labor, a fair chance at some station in life, a fair account of one's character" may in fact be matters of property in important ways (97-98). So a more egalitarian conclusion may be founded on the importance of property than perhaps some people might realize.

Maybe Hume's justice as property and Beauvoir's equal freedom are both elements of a prior and higher goal of human inventiveness aimed at humanity. Does it make a difference whether equal rights are defined as property rights or a matter of freedom, or as a matter of humanity? Only if justice and freedom 
are somehow considered more important or more fundamental than humanity. But are they? Why are justice or freedom the most important thing? Maybe humanity is more important. In that case, Hume's theory of justice is just a theory of property which aims to do no more or no less than take care of the problems that are created by instability of property and Simone of Beauvoir's concerns with freedom are no more and no less than a vindication of freedom in contexts of ambiguity. And both are components of humanity. 


\section{Referencias bibliográficas:}

\section{Fuentes primarias:}

Beauvoir, S. de, "An Eye for an Eye" in Simone de Beauvoir: Philosophical Writings (Urbana: University of Illinois Press, 2004).

, Le Deuxième Sexe (Paris: Gallimard, 1949). English edition, The Second Sex, tr. Constance Borde and Sheila Malovany-Chevallier (New York: Vintage Books, 2009).

, "Moral Idealism and Political Realism" in Simone de Beauvoir: Philosophical Writings (Urbana: University of Illinois Press, 2004).

, Pour une morale de l'Ambiguité (Paris: Gallimard, 1947). English edition, The Ethics of Ambiguity, tr. B. Fruchtman (New York: Philosophical Library, 1948).

, Pyrrhus and Cineas, in Simone de Beauvoir: Philosophical Writings (Urbana: University of Illinois Press, 2004).

"What is Existentialism?" (1947) in Simone de Beauvoir: Philosophical Writings (Urbana: University of Illinois Press, 2004).

\section{Estudios:}

Baier, A., The Cautious Jealous Virtue: Hume on Justice (Cambridge: Harvard University Press, 2010

Becker, L., Property Rights: Philosophic Foundations (London: Routledge and Kegan Paul, 1977).

Church, J. "Selfish and Moral Politics: David Hume on Stability and Cohesion in the Modern State", The Journal of Politics, 69, 2007.

Farneth, M., "James Baldwin, Simone de Beauvoir, and the 'New Vocabulary' of Existentialist Ethics", Soundings: An Interdisciplinary Journal, 96, 2013.

Haakonssen, K., The Science of a Legislator (Cambridge: Cambridge University Press, 1981).

Hough, S., "Humean Androgynes and the Nature of "Nature" in Feminist Interpretations of David Hume, ed. Anne Jaap Jacobson (University Park: Pennsylvania State University Press, 2000).

Hume, D., A Treatise of Human Nature, eds. David and Mary Norton (Oxford: Oxford University Press, 2000).

, Enquiry concerning the Principles of Morals, ed. L. A. Selby-Bigge (Oxford: Clarendon Press, Third Edition, 1975).

Kruks, S., "Ambiguity and Certitude in Simone de Beauvoir's Politics", $P M L A$, 124, 2009. 
Laursen, J. C., "David Hume on custom and habit and living with skepticism", Daimon: Revista Internacional de Filosofia 52, 2011, 87-99.

Le Doeuff, M., "Simone de Beauvoir and Existentialism", Feminist Studies, 6, 1980.

Okin, S.M., "Justice and Gender", Philosophy and Public Affairs, 16, 1987.

Sandel, M., Justice: What's the Right Thing to Do? (New York, Farrar, Straus, 2009). 
